\title{
PERANCANGAN SISTEM INFORMASI SIRKULASI BUKU PADA PERPUSTAKAAN SMP NEGERI 103 JAKARTA
}

\author{
Lucky Adnin Pratama ${ }^{1}$, Alusyanti Primawati ${ }^{2}$, Lusi Ariyani ${ }^{3}$ \\ Program Studi Informatika, Universitas Indraprasta PGRI \\ ladnin59@gmail.com ${ }^{1}$,alus.unindra23@gmail.com ${ }^{2}$,lusiariyani0312@gmail.com³
}

Submitted July 25, 2019: Revised September 23, 2019, Accepted November 10, 2019

\begin{abstract}
Abstrak
Perkembangan teknologi informasi dan komunikasi seharusnya memberikan dampak dalam pengelolaan perpustakaan, perpustakaan merupakan tempat untuk seorang mencari referensi buku untuk dibaca, mencari tugas atau dipinjam pada umumnya, masih banyak perpustakaan yang masih menggunakan sistem manual seperti pencatatan pada buku, begitu juga dengan perpustakaan di SMP Negeri 103 Jakarta, metode yang digunakan dalam penelitian ini adalah Grounded Research. Salah tujuan dari penelitian ini adalah membuat perancangan sistem informasi sirkulasi buku pada Perpustakaan SMP Negeri 103 Jakarta ditinjau dari pendataan peminjaman buku dan pengembalian buku, serta pembuatan laporan data peminjaman buku perpustakaan. Sehingga hasil dari penelitian ini adalah model dan aplikasi dari sistem informasi sirkulasi buku perpustakaan untuk dimanfaatkan oleh Perpustakaan SMP Negeri 103 Jakarta.
\end{abstract}

Kata Kunci : Sistem Informasi, Sirkulasi Buku, Perpustakaan.

\begin{abstract}
The development of information and communication technology should have an impact on library management, the library is a place for a person to find reference books to read, look for assignments or borrow in general, there are still many libraries that still use manual systems such as recording books, as well as libraries in SMP Negeri 103 Jakarta, the method used in this study is Grounded Research. One of the objectives of this research is to Make a Book Circulation Information System Design at the 103 Jakarta Junior High School Library in terms of data collection on book lending and book return, as well as making library book loan data reporting. Sahingga results of this study are the Model and Application of the Library Book Circulation Information System for use by the Jakarta 103 Junior High School Library.
\end{abstract}

Key Words : Information System, Book Circulation, Library

\section{PENDAHULUAN}

Perkembangan teknologi informasi dan komunikasi seharusnya memberikan dampak dalam pengelolaan perpustakaan. Tujuan perpustakaan adalah untuk menyediakan fasilitas dan sumber informasi dan menjadi pusat pembelajaran. Definisi lain menyatakan bahwa perpustakaan berfungsi untuk mengenalkan teknologi informasi. Perkembangan teknologi informasi harus terus diikuti pelajar dan pengajar. Untuk itu perlu proses pengenalan dan penerapan teknologi informasi dari perpustakaan.
Perpustakaan merupakan tempat untuk seorang mencari referensi buku untuk dibaca, mencari tugas atau dipinjam [1]. Pada umumnya masih banyak perpustakaan yang masih menggunakan sistem manual seperti pencatatan pada buku, begitu juga dengan perpustakaan di SMP Negeri 103 Jakarta. Layanan perpustakaan bertujuan untuk memberikan informasi guna meningkatkan pengetahuan dan kemampuan, serta menunjang proses belajar mengajar, menunjang program lembaga tertentu, melestarikan budaya bangsa, dan memperlancar tugas 
penelitian, serta sebagai tempat memperoleh informasi.

Kata sirkulasi berasal dari bahasa Inggris circulation yang berarti perputaran atau peredaran[2]. Dalam ilmu perpustakaan, sirkulasi sering disebut sebagai bagian peminjaman, yaitu suatu pekerjaan, tugas, kegiatan yang berhubungan dengan pemanfaatan koleksi perpustakaan oleh pemakai perpustakaan [6].

Dengan pengertian tersebut dapat dipahami bahwa bagian sirkulasi adalah kegiatan layanan yang menangani urusan peminjaman, pengembalian, pendaftaran keanggotaan perpustakaan, penentuan denda, pemesanan peminjaman bahan pustaka, penggerakan bahan pustaka yang selesai digunakan, pencatatan pemanfaatan koleksi pembuatan statistik keterpakaian bahan pustaka.

Layanan sirkulasi hampir ada disemua jenis perpustakaan yang menyelenggarakan kegiatan layanan karena layanan ini merupakan kegiatan utama penyelenggaraan layanan perpustakaan. Sering kali disebutkan bahwa layanan sirkulasi merupakan salah satu indikator utama keberhasilan suatu perpustakaan[4]. Oleh karena dari kegiatan layanan ini maka dapat diketahui sejauh mana keterpakaian koleksi yang dimiliki perpustakaan digunakan oleh pemakainya. Dengan demikian, dapat disimpulkan bahwa untuk mencapai keberhasilan sebuah perpustakaan dalam memenuhi berbagai kebutuhan informasi pemakainya, yaitu salah satunya dapat dilihat dari sejauh mana kegiatan layanan sirkulasi beraktivitas. Kesibukan yang terjadi di bagian sirkulasi mencerminkan bahwa perpustakaan tersebut sepenuhnya dipergunakan oleh pemakai.

Dengan siswa yang tidak sedikit sistem manual tersebut sangat tidak efektif dalam penyimpanan dan sangat tidak efisien, maka perlu media untuk mempermudah petugas dalam mendata buku, mendata anggota, mengetahui denda, dan juga dapat meminimalisir kesamaan dalam pendataan bagi siswa dalam peminjaman buku yang ada pada perpustakaan tersebut. Melihat kendala pada perpustakaan disekolah SMP Negeri 103 Jakarta yang masih menggunakan sistem manual yang akan menyulitkan petugas dan juga siswa.

Tujuan dari penelitian ini adalah :

a. Membuat Perancangan Sistem Informasi Sirkulasi Buku Pada Perpustakaan SMP Negeri 103 Jakarta ditinjau dari pendataan peminjaman buku dan pengembalian buku, serta pembuatan laporan data peminjaman buku perpustakaan.

b. Memudahkan kepala perpustakaan SMP Negeri 103 Jakarta dalam penyimpanan data buku dan data anggota perpustakaan.

c. Agar peminjaman, pengembalian dan laporan buku di SMP Negeri 103 Jakarta lebih efektif dan efisien.

Manfaat dari rancangan sistem informasi sirkulasi buku yang dihasilkan:

a. Membantu pihak perpustakaan SMP Negeri 103 Jakarta dalam mengelola administrasi buku seperti peminjaman, pengembalian dan laporan buku perpustakaan menjadi lebih mudah dan efisien.

b. Meningkatkan proses pendataan buku menjadi lebih efektif dan efisien.

c. Menghemat waktu pembuatan Laporan perpustakaan sehingga dapat disesuaikan dengan kebutuhan pelaporan perpustakaan disekolah

\section{METODE PENELITIAN}

Penulis menggunakan metode Grounded Research dalam penelitian dengan menggunakan data empiris maka dilakukan pengembangan sistem dari manual menjadi terkomputerisasi.

Metode yang digunakan dalam penelitian ini adalah metode kualitatif dengan 
pendekatan deskriptif, makna penelitian kualitatif tidak terbatas pada urusan data, objek kajian, atau bahkan prosedur penelitian, makna penelitian kualitatif sungguh tidak mudah diskripsikan, tetapi bisa dipahami ciri-ciri khasnya, salah satu ciri khasnya yang sangat penting adalah kebenaran [3].

Dalam pengumpulan data, keterangan dan rancangan program yang dibutuhkan untuk perancangan sistem berbasis komputer yang terdapat di perpustakaan SMP Negeri 103 Jakarta. Penulis menggunakan 3 (tiga) metode yaitu :

1. Observasi (pengamatan langsung)

Observasi dilakukan dengan mendatangi llangsung dan survey terhadap objek secara langsung untuk mendapatkan informasi dasar yang dibutuhkan terhadap objek yang diteliti. Observasi ini dilakukan pada bulan April, bertempat di perpustakaan SMP Negeri 103 Jakarta.

Penelitian ini dimulai dengan permintaan izin melakukan penelitian kepada Bapak Sudarto selaku Kepala Sekolah di SMP Negeri 103 Jakarta, guna melengkapi kebutuhan sistem program skripsi Perancangan Sistem Informasi Sirkulasi Buku sekolah. Selanjutnya penulis melakukan studi lapangan dengan bertanya kepada kepala perpustakaan terhadap kegiatan perpustakaan sekolah, diantaranya pencatatan, pengolahan, penyimpanan, data-data perpustakaan serta pembuat laporan.

2. Interview (wawancara)

Penulis sebagai pewawancara (interviewer) melakukan tatap muka/ interaksi langsung kepada orang yang diwawancarai diantaranya:

a. Kepala Sekolah SMP Negeri 103 Jakarta, untuk mengetahui kebijakan mengenai sistem informasi perpustakaan sekolah.

b. Kepala perpustakaan SMP Negeri 103 Jakarta, karena pihak ini bertanggung jawab dengan kondisi dan situasi perpustakaan sekolah

c. Guru dan Siswa SMP Negeri 103 Jakarta, untuk mengetahui keperluan dan kepentingan mereka terhadap perpustakaan sekolah.

3. Dokumentasi

Penulis melakukan pengumpulan data dengan cara melihat dan mencatat data yang ada pada dokumen atau arsip perpustakaan SMP Negeri 103 Jakarta.

\section{Langkah - langkah Pengembangan Sistem}

Dalam membuat langkah-langkah pengembangan sistem, digunakan metode terstruktur dengan paradigma siklus hidup klasik. Paradigma siklus hidup klasik memiliki beberapa kelebihan yaitu:

a. Titik Awal dan titik akhir yang eksplisit.

b. Setiap tahapan didefinisikan dengan jelas.

c. Setiap akhir satu tahap, disesuaikan dengan tahap sebelumnya, sehingga kesalahan yang mungkin terjadi bisa ditemukan dan disesuaikan lebih dini.

d. Incremental release, lingkup kerja untuk tahapan-tahapan berikut menjadi lebih kecil, dan tugas yang lebih mudah, jika tahap awal yang dilakukan dengan benar maka akan mempermudah tahapan berikut.

Paradigma siklus hidup klasik untuk pengembangan sistem diilustrasikan seperti gambar dibawah: 


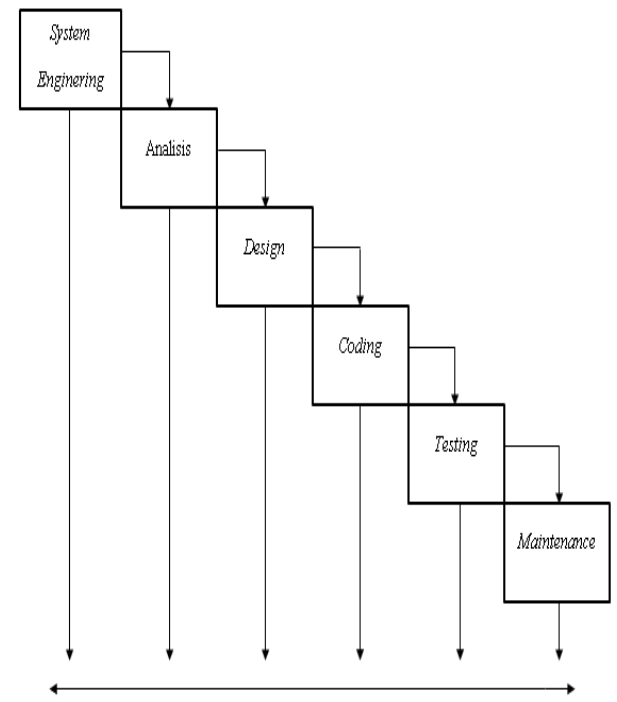

Gambar 1. Model Air Terjun

Berikut penjelasan aktivitas dan setiap tahapan paradigma siklus hidup klasik yang diterapkan pada sistem informasi perpustakaan di SMP Negeri 103 Jakarta adalah:

1. System enginering

Dalam tahap ini penulis melakukan pengumpulan kebutuhan seluruh elemen sistem seperti data-data yang digunakan, dimana elemen-elemen itu dapat memanjang dalam pengembangan sistem administrasi.

2. Requitments Analysis

Kemudian ditahap menganalisa sistem dilakukan pengumpulan kebutuhan dengan fokus pada perangkat lunak, meliputi informasi, fungsi masingmasing pada bagian sistem, kerja atau cara kerja antarmuka. Lalu menyediakan perangkat dan teknik yang dapat membantu penulis untuk menentukan kebutuhan melalui sistem yang telah berjalan pada sistem informasi sirkulasi buku perpustakaan di SMP Negeri 103 Jakarta dalam melakukan pengolahan data-datanya. Perangkat yang dimaksud adalah penggunaan Diagram Alir Data (DAD) untuk menyusun data input, proses dan output fungsi bisnis.
3. Design

Pada tahap ini dilaksanakan perancangan struktur data, arsitektur perangkat lunak, rincian prosedural, karakteristik antar muka dilaksanakan pada tahap ini dan dirancang tampilan layar seperti form-form masukan dan form keluaran dari sistem yang akan dirancang.

4. Testing

Sebelum sistem informasi visual menajemen sistem dapat digunakan dengan baik harus dilakukan pengujian terlebih dahulu. Rangkaian penguji ini dijalankan bersama-sama dengan data aktual dari sistem yang sudah ada atau sistem yang sedang berjalan.

\section{Maintenance}

Bagian terujung dari siklus penembangan sistem administrasi dan tahap yang dilakukan setelah perangkat lunak dipergunakan yaitu kegiatan corrective maintenance. Correntive maintenance adalah mengoreksi kesalahan pada perangkat lunak, yang baru diketahui pada saat perangkat lunak yang dipergunakan. Dengan ada corrective maintenance terhadap visual manajemen sistem maka kesalahankesalahan sistem ini dapat diperbaiki.

\section{HASIL DAN PEMBAHASAN}

Dari hasil penelitian yang penulis lakukan, maka dapat diambil beberapa masalah yang dapat diuraikan sebagai berikut:

1. Proses pencatatan secara manual memerlukan tempat penyimpanan yang sangat luas, akibat kertas yang bertumpuk serta memerlukan waktu yang cukup lama dalam proses pencarian data kembali.

2. Penulisan data buku masih dilakukan secara manual sehingga pelayanan terhadap anggota menjadi tidak efisien dan mungkin akan terjadi kesalahan dalam proses peminjaman. 


\section{Alternatif Penyelesaian Masalah}

Berdasarkan analisa yang berjalan saat ini penulis melihat kelemahan-kelemahan dan pokok permasalahan yang terdapat pada Sistem Informasi Sirkulasi Buku Pada Perpustakaan SMP Negeri 103 Jakarta, maka penulis dapat menyarankan beberapa alternatif pemecahan permasalahan yang dapat dicoba yaitu:

1. File ataupun data yang sudah dikerjakan sebaiknya disimpan ke harddisk atau alat penyimpanan data lain yang berbentuj digital, dan jika perlu dibuat backup-nya jika disuatu saat terjadi kesalahan atau suatu yang tidak diinginkan perpustakaan sekolah SMP Negeri 103 Jakarta masih memiliki cadangan file ataupun datadatanya.

2. Dengan dibuatnya perancangan sistem informasi sirkulasi buku dengan sistem yang terkomputerisasi ini diharapkan dapat mempermudah proses administrasi data khususnya pada proseds pembuatan laporan dan pengolahan data buku.

Diagram Alir Data (DAD) Sistem yang Diusulkan

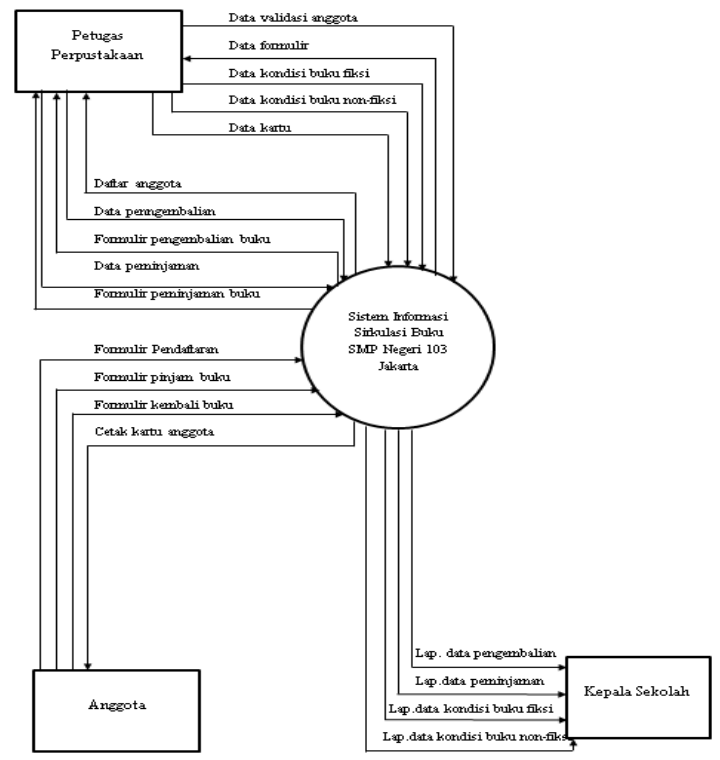

Gambar 2. Diagram Kontek Sistem yang Diusulkan
Perancangan Sistem Infromasi Sirkulasi Buku Pada Perpustakaan SMP Negeri 103 Jakarta dibangun dengan bahasa pemrograman java. Java adalah bahasa pemrograman yang dapat dijalankan dibeberapa perangkat elektronik seperti komputer, telepon genggam dan perangkat lain yang mendukung java. Java tidak tergantung dengan platform dimana ia dijalankan, dengan kata lain java bisa dijalankan di beragam sistem operasi seperti Windows, Linux, Macintos dan lainnya [5].

\section{Tampilan Layar Sistem Informasi Sirkulasi Buku Perpustakaan}

Pada tampilan awal adalah tampilan login untuk masuk kedalam menu aplikasi, untuk login masukan username dan password dan terdapat pula icon hapus pada kanan bawah untuk menghapus semua inputan.

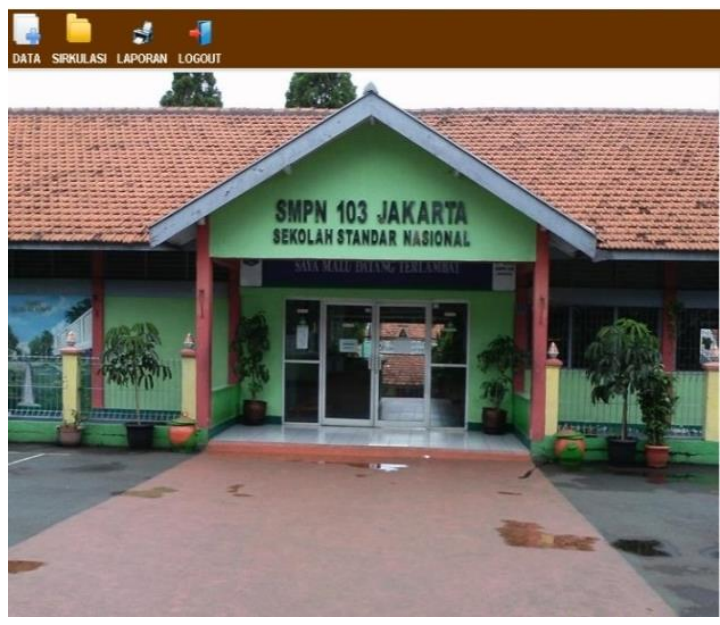

Gambar 3. Tampilan Form Menu Utama

Pada tampilan menu terdapat beberapa menu yang berada di atas kiri, terdapat menu data yang berisi data-data buku dan anggota perpustakaan, menu sirkulasi berisi aktivitas peminjaman dan pengembalian buku perpustakaan, laporan untuk kegiatan percetakan laporan, dan logout adalah untuk keluar dari menu. Selanjutnya pada tampilan form masukan, merupakan awal dari kegiatan sirkulasi perpustakaan dimulai dengan mendaftar 
calon anggota perpustakaan, terdapat beberapa kolom yang harus diisi, dan beberapa pilihan yang harus dipilih. ada beberapa tombol untuk beberapa fungsi seperti save untuk menyimpan data edit untuk mengubah data delete untuk menghapus data reset untuk membersihkan tampilan kolom dan tombol buat kartu, untuk memasuki form pembuatan kartu anggota.

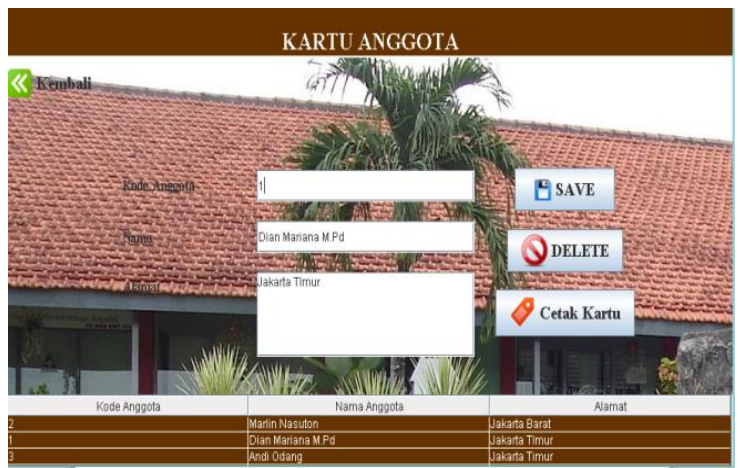

\section{Gambar 4. Tampilan Form Kartu Anggota}

Pada tampilan masukan kartu anggota, data anggota yang sudah diinput tinggal dipangil dengan mengetikan beberapa kode maka akan muncul data anggota untuk kartu anggotannya, yang akan dicetak sebagai kartu anggota tidaklah semua isi data anggota melainkan hanya beberapa isi identitas saja. terdapat tombol cetak kartu untuk masuk ke tampilan pencetakan atau jasperviewer kartu.

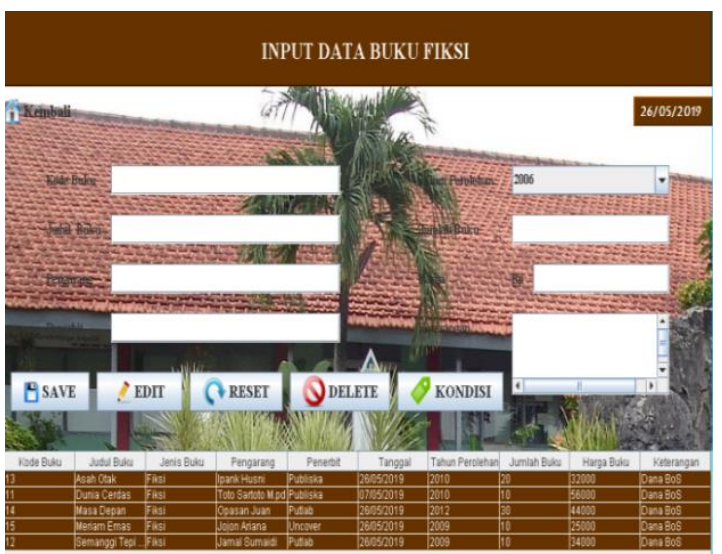

Gambar 5. Tampilan Form Data Buku Fiksi

Pada tampilan masukan data buku fiksi, buku fiksi yang telah dipilih kemudia data- datanya dimasukan kedalam form masukan data buku fiksi, ada beberapa kolom yang harus diisi dan pilihan yang harus dipilih, terdapat tombol kondisi untuk menampilkan form masukan kondisi buku fiksi.

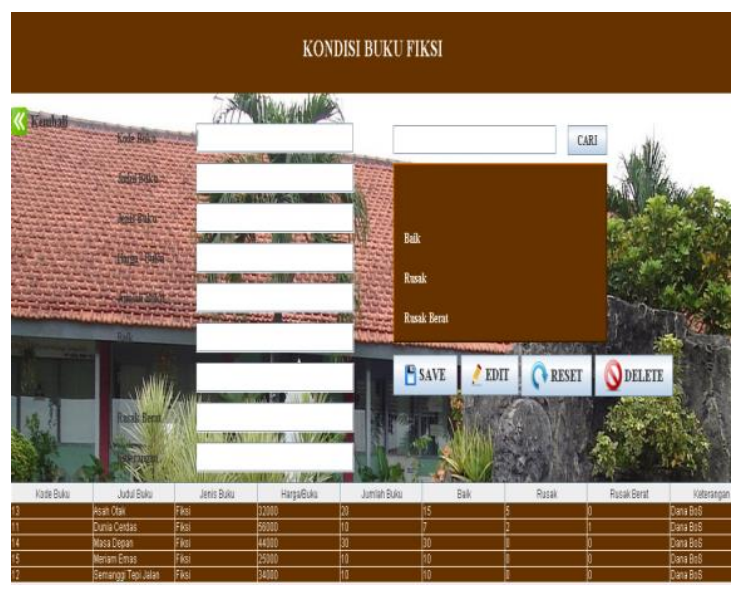

Gambar 6. Tampilan Form Kondisi Data Buku Fiksi

Pada tampilan masukan data kondisi buku fiksi, buku fiksi yang sudah dimasukan lalu dipanggil kembali dengan memasukan kode buku fiksi, lalu data buku fiksi akan masuk dan masukan berapa buku yang kondisi baik, rusak dan rusak berat, klik save untuk simpan data kondisi buku fiksi.

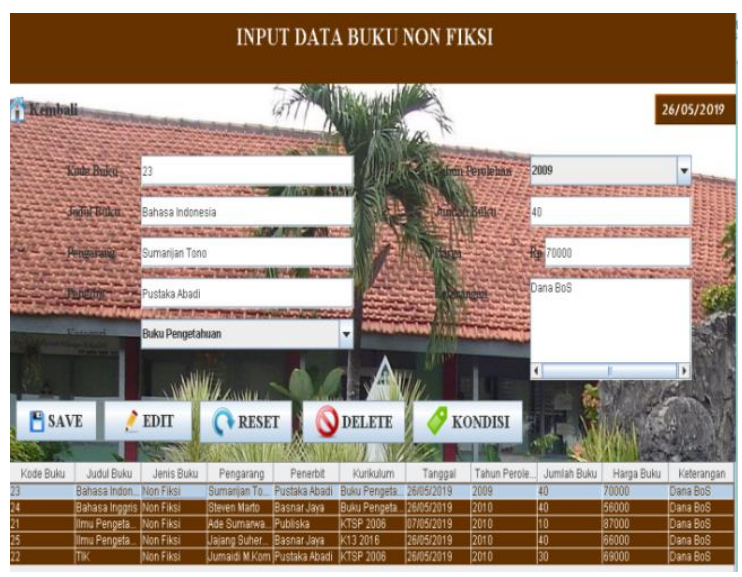

Gambar 7. Tampilan Form Data Buku NonFiksi

Pada tampilan masukan data buku nonfiksi, buku non-fiksi yang telah dipilih kemudia data-datanya dimasukan kedalam form masukan data buku fiksi, ada beberapa kolom yang harus diisi dan 
pilihan yang harus dipilih, terdapat tombol kondisi untuk menampilkan form masukan kondisi buku non-fiksi.

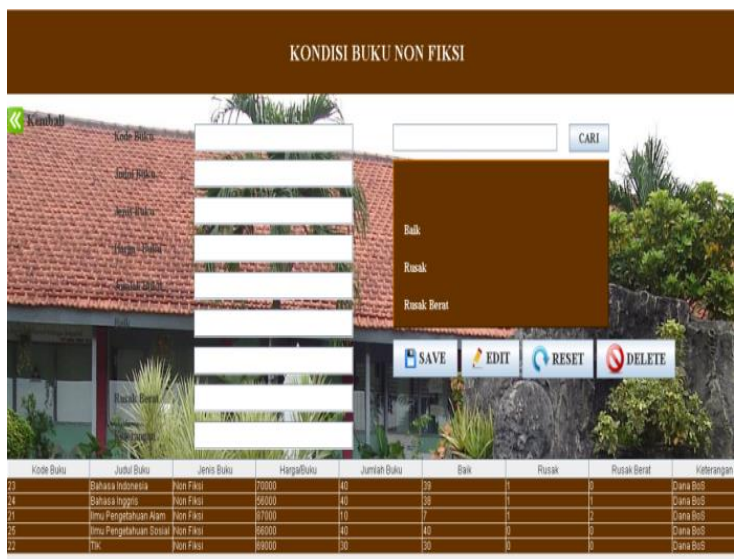

Gambar 8. Tampilan Form Kondisi Data Buku Non-Fiksi

Pada tampilan masukan data kondisi buku non-fiksi, buku non-fiksi yang sudah dimasukan lalu dipanggil kembali dengan memasukan kode buku non-fiksi, lalu data buku non-fiksi akan masuk dan masukan berapa buku yang kondisi baik, rusak dan rusak berat, klik save untuk simpan data kondisi buku non-fiksi.

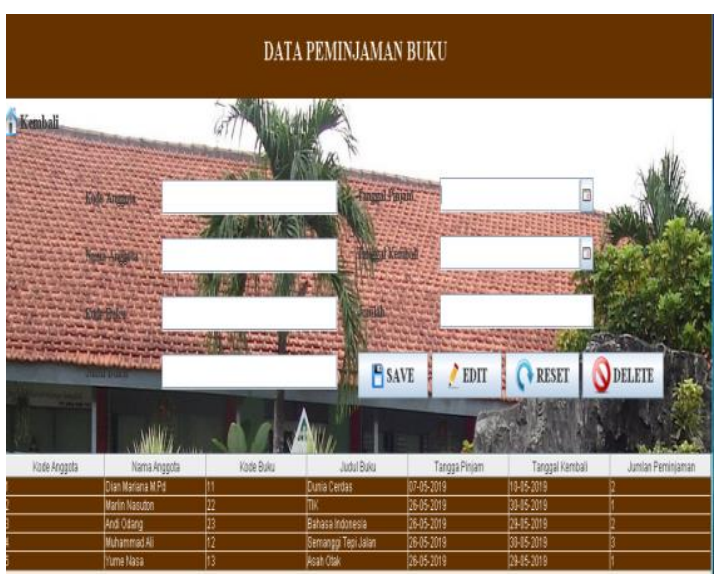

Gambar 9. Tampilan Form Data Peminjaman

Pada tampilan masukan data peminjaman, anggota yang meminjam buku akan dimasukan data anggotanya dan juga data buku yang dipinjam, apakah itu buku fiksi maupun buku non-fiksi, adapun masukan tanggal untuk memilih kapan buku harus dikambilan, pilih tombol save untuk menyimpan data peminjaman.

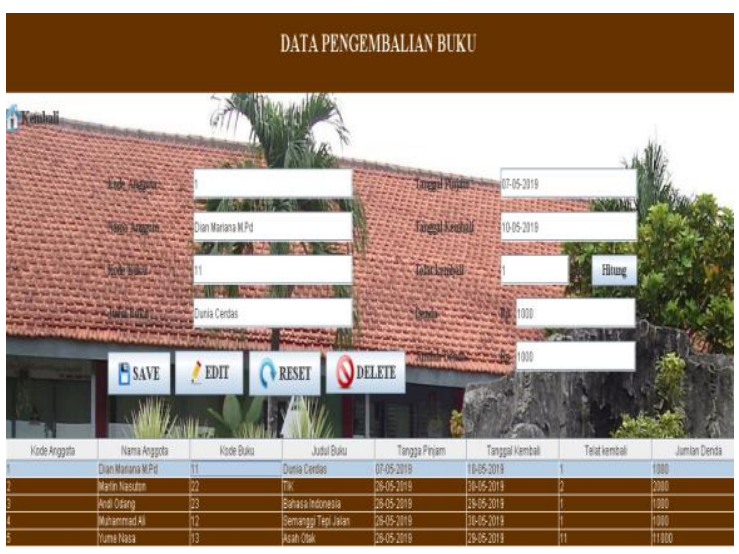

Gambar 10. Tampilan Form Data Pengembalian

Pada tampilan masukan data pengembalian, anggota yang mengembalikan buku akan dimasukan kembali data anggotanya dan juga data buku yang dipinjam, dalam pengembalian tinggal memasukan kode anggota dan kode buku maka akan menampilkan tanggal peminjaman, jika tanggal pengembalian telah jatuh tempo maka fitur denda dapat dikenakan dan dihitung dari hari terlambatnya pengembalian buku.

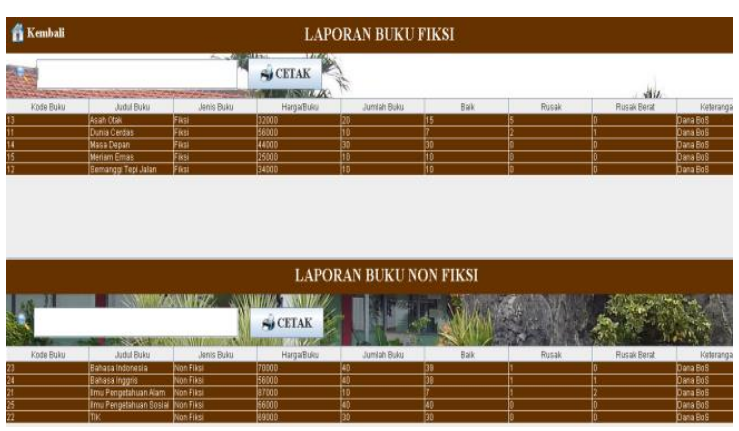

Gambar 11. Tampilan Form Laporan Buku Fiksi dan Non-Fiksi

Pada tampilan keluaran laporan buku fiksi dan non-fiksi, menampilkan tabel dari kondisi buku fiksi dan kondisi buku nonfiksi yang menjadi laporan akhir buku fiksi dan buku non-fiksi, terdapat kolom cari mencari data buku fiksi atau non-fiksi, dan terdapat tombol cetak buku fiksi atau non- 
fiksi, menekan tombol cetak akan masuk ke tampilan jasperviewer.

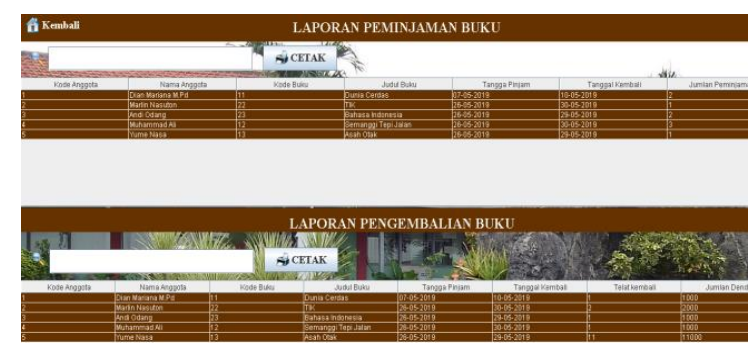

Gambar 12. Tampilan Form Laporan Peminjaman dan Pengembalian

Pada tampilan keluaran laporan peminjaman dan pengembalian, menampilkan tabel dari peminjaman dan pengembalian yang menjadi laporan akhir peminjaman dan pengembalian, terdapat kolom cari mencari data peminjaman dan pengembalian, dan terdapat tombol cetak peminjaman dan pengembalian, menekan tombol cetak akan masuk ke tampilan jasperviewer.

\section{SIMPULAN}

Berdasarkan dari pembahasan di atas, maka penulis mengambil kesimpulan sebagai berikut:

1. Perancangan Sistem Informasi Sirkulasi Buku Pada Perpustakaan SMP Negeri 103 Jakarta berhasil dibuat dengan menggunakan Netbeans 8.2.

2. Pembuatan sistem informasi ini menampilkan jalannya sistem di perpustakaan SMP Negeri 103 Jakarta sesuai dengan data riset yang diterima penulis.

3. Sistem informasi sirkulasi buku ini dapat dapat memudahkan petugas perpustakaan dalam melakukan pekerjaan administrasi peminjaman buku dan pembuatan laporan bulanan.

4. Sistem informasi sirkulasi buku yang berbasis desktop ini dapat dijalankan kapan saja saat petugas akan melakukan transaksi peminjaman dan menyerahkan laporan kepada kepala sekolah.

\section{DAFTAR PUSTAKA}

[1] S. Rosliana, Herlawati, and A. Supriyatna, Sistem Informasi Peminjaman Dan Pengembalian Buku Pada Perpustakaan Smp Negeri 20 Bekasi, J. Sist. Inf., vol. 4, no. 2, pp. 215-233, 2015.

[2] S. R. Armando, Sistem informasi sirkulasi buku pada perpustakaan sekolah, 2017.

[3] D. Gustina, A. Sumbaryadi, and R. Nurbaeti, Sistem Informasi Pengolahan Data Perpustakaan Berbasis Desktop Pada Yayasan Pendidikan Tanimbar Lestari, IkraithInformatika, vol. 2, no. 1, pp. 48-56, 2018.

[4] Yogi.A, Perancangan Apliksi Perpustakaan Berbasis Desktop di SMAN 9 Garut, 2016.

[5] A. Afriansyah, Politeknik Sekayu Menggunakan Pemrograman Java, vol. III, no. 2, pp. 53-61, 2015.

[6] H. N. 2015 Perwira, Pengembangan Sistem Informasi Perpustakaan Berbasis Web di SMK Muhammadiyah 1 Yogyakarta, pp. 1170, 2015. 